\title{
Differential intake of D- and L-tryptophan by serotonin-deficient and normal Rattus norvegicus DAB stocks
}

\author{
ETHEL TOBACH and TERESA PACHECO HERNANDEZ \\ The American Museum of Natural History, New York, New York \\ and Hunter College, New York, New York
}

\begin{abstract}
The Fawnhooded (FH) rat, Rattus norvegicus, is an apparently spontaneous mutant in both laboratory and wild stocks. It is deficient in serotonin in blood platelets and in the pineal, and has prolonged bleeding times. It also has shown a readiness to drink bitter-tasting substances (cyclohexamide and phenylthiocarbamide) in greater quantities than other rat stocks. This study was undertaken to investigate whether the FH rat would also drink a bitter-tasting substance which might have physiological significance. In three experiments, FH and normal Wistar (W) rats were given bitter-tasting L-tryptophan (L-t), phenylthiocarbamide (PTC), sweet-tasting Dtryptophan (D-t), and saccharin (S) and water in various combinations in two-bottle presentations. FH rats drank more L-t than did W rats, and W rats drank more D-t than did FH rats, although both stocks drank S and PTC freely. W rats drank more S than FH rats, whereas FH rats drank more PTC than $W$ rats. These stocks may have different receptor sites for $S$, PTC, and the two tryptophans. These differential receptor characteristics may be related to the $\mathrm{FH}$ stock's serotonin deficiency.
\end{abstract}

Fawnhoodedness in offspring of parents with a variety of coat colors (Silver, Hernandez, \& Tobach, 1988), as represented in the Fawnhooded $(\mathrm{FH})$ rat (Raymond \& Dodds, 1975), is an apparently spontaneous genetic mutation in Rattus norvegicus. This mutation is accompanied by a blood platelet serotonin deficiency leading to increased bleeding time (Tschopp \& Zucker, 1972). Also, the FH rat has been found to drink concentrations of bittertasting substances that are rejected by "normal" rats (Tobach, Bellin, \& Das, 1974). L-tryptophan (L-t), the precursor of serotonin, is bitter. Would the fawnhooded rat drink L-t more readily than a normal rat?

This question has some bearing on at least two phenomena: (1) compensatory intake by organisms that are deficient in life-supporting substances, and (2) the conconcomittance of a number of characteristics in the FH rat, namely, a particular coat color (Tobach, DeSantis, \& Zucker, 1984), slow development (Pacheco, 1986), a specialized taste sensitivity, and serotonin deficiency. With respect to the second phenomenon, substantive information about some biochemical system common to apparently unrelated characteristics may be helpful in understanding the pleiotropic character of genetic variation.

Data for the FH and $\mathrm{W}$ animals are from the master's thesis of T. Pacheco Hernandez (Pacheco, 1986), and are presented here as Experiment 1 . Copies of the thesis are available at cost of reproduction from Ms. Hernandez at address given below. The research was supported by the Biopsychology Program of Hunter College and the Department of Mammalogy of the American Museum of Natural History. Address correspondence to E. Tobach, Curator, Department of Mammalogy, American Museum of Natural History, Central Park West at 79th Street, New York, NY 10024-5192.
As for the first phenomenon, it is as yet an unresolved issue, but evidence of differential intake of a significant substance by deficient individuals may help resolve it. In addition, an affirmative answer to the question asked about the response to L-t would suggest the possibility that taste sensitivity plays some role in the growth and development pattern of the $\mathrm{FH}$ rat.

\section{METHOD}

\section{Animals Studied}

Four femalas and 4 males of similar ages of the FH and Wistar (W) stocks were studied in each of three experiments; each group served in only one experiment. The two stocks differ in growth patterns (Rosoff, Yamashita, \& Tobach, 1985; Pacheco, 1986), and accordingly, there were differences in weights and in food and fluid intake (see Tables 1 and 2). These differences, however, were not related to the differential intake of the experimental fluids (see below). A reversed light cycle ( $12 \mathrm{h:12}$ h) was maintained in the colony room, which was kept at $68^{\circ}-72^{\circ} \mathrm{F}$ at all times. Room lights were on during regular colony routine (e.g., feeding, weighing, cage changes) and removal and presentation of fluids and food.

\section{Procedure and Experimental Materials}

In all three experiments, the animals were given fluids in a twobottle presentation. Combinations and their sequences were counterbalanced, as were right-left presentations. Tap water was used to make all solutions.

Tap water was given in the two bottles for 1 week before the experimental fluids were presented in each experiment. In Experiment 1 , the rats were given combinations of tap water and a .05 M solution of either D-tryptophan (D-t) or L-t for 2 weeks, in counterbalanced positions and combinations of all three fluids. To determine if the rats were drinking L-t or D-t on the basis of taste, in Experiment 2 they were given a $.01 \mathrm{M}$ solution of saccharin (S) 
Table 1

Ages and Weights of Fawnhooded and Wistar DAB Rat Stocks in Each Experiment

\begin{tabular}{|c|c|c|c|c|c|c|c|c|}
\hline \multirow{3}{*}{$\begin{array}{c}\text { Rat } \\
\text { Stock }\end{array}$} & \multirow{3}{*}{$\begin{array}{c}\text { Number } \\
\text { of Rats }\end{array}$} & \multirow{3}{*}{$\begin{array}{c}\text { Number } \\
\text { of Litters } \\
\text { Represented }\end{array}$} & \multirow{2}{*}{\multicolumn{2}{|c|}{$\begin{array}{c}\text { Age (Days) } \\
\text { at Start of Experiment }\end{array}$}} & \multicolumn{4}{|c|}{ Body Weights (Grams) } \\
\hline & & & & & \multicolumn{2}{|c|}{ At Start of Experiment } & \multicolumn{2}{|c|}{ At End of Experiment } \\
\hline & & & Median & Range & Median & Range & Median & Range \\
\hline \multicolumn{9}{|c|}{ Experiment 1} \\
\hline $\begin{array}{l}\mathbf{F H} \\
\mathbf{W}\end{array}$ & $\begin{array}{l}8 \\
8\end{array}$ & $\begin{array}{l}5 \\
6\end{array}$ & $\begin{array}{r}106 \\
92\end{array}$ & $\begin{array}{l}78-115 \\
75-166\end{array}$ & $\begin{array}{l}185 \\
197\end{array}$ & $\begin{array}{l}131-226 \\
154-301\end{array}$ & $\begin{array}{l}208 \\
218\end{array}$ & $\begin{array}{l}185-235 \\
172-336\end{array}$ \\
\hline \multicolumn{9}{|c|}{ Experiment 2} \\
\hline $\begin{array}{l}\text { FH } \\
\mathbf{W}\end{array}$ & $\begin{array}{l}8 \\
8\end{array}$ & $\begin{array}{l}6 \\
5\end{array}$ & $\begin{array}{l}148 \\
154\end{array}$ & $\begin{array}{l}127-158 \\
148-163\end{array}$ & $\begin{array}{l}186 \\
260\end{array}$ & $\begin{array}{l}154-215 \\
214-301\end{array}$ & $\begin{array}{l}190 \\
290\end{array}$ & $\begin{array}{l}159-277 \\
238-349\end{array}$ \\
\hline \multicolumn{9}{|c|}{ Experiment 3} \\
\hline $\begin{array}{l}\text { FH } \\
\mathbf{W}\end{array}$ & $\begin{array}{l}8 \\
8\end{array}$ & $\begin{array}{l}6 \\
4\end{array}$ & $\begin{array}{l}77 \\
87\end{array}$ & $\begin{array}{l}76-97 \\
73-105\end{array}$ & $\begin{array}{l}170 \\
268\end{array}$ & $\begin{array}{l}141-239 \\
189-302\end{array}$ & $\begin{array}{l}196 \\
271\end{array}$ & $\begin{array}{l}150-253 \\
193-309\end{array}$ \\
\hline
\end{tabular}

Note-The two stocks were close in age in each experiment (Mann-Whitney $U$ tests in all experiments yielded $p$ values of >.10; Siegel, 1956). Differences between the weights of the two stocks were all statistically significant (Mann-Whitney $U$ tests, $p<.01$ ) in all experiments. This was true at the beginning and at the end of each experiment (see text). FH $=$ Fawnhooded; $\mathbf{W}=$ Wistar.

as a sweet-tasting substance, and in Experiment 3 they were given a $.03 \mathrm{M}$ solution of phenylthiocarbamide (PTC), as a bitter-tasting substance, in combination with the water, D-t, or L-t solutions. Seven people, who were given all seven fluids in one session in a Latin square design (see Pritchard \& Scott, 1982), judged the $S$ and PTC solutions to be equivalent in taste to D-t and L-t.

The rats were given tap water from 1200 to $1300 \mathrm{~h}$ daily. At $1200 \mathrm{~h}$, they were given $20 \mathrm{~g}$ Laboratory Rat Chow; uneaten chow was removed at $0900 \mathrm{~h}$ the next day. Experimental fluids were presented from 0900 to 1100 h on Tuesday through Friday. Chow and tap water were available ad lib on the weekends. Fluid and food intake were recorded by weight (grams) differences between the amounts given and the remainders.

\section{RESULTS}

Table 3 shows the total intake of the various fluids by the two stocks in each of the three experiments. Betweenstock comparisons of the intake of fluids were carried out using Mann-Whitney $U$ tests; within-stock comparisons of intake were made using the sign test (Siegel, 1956). In all three experiments, FH rats drank more $\mathrm{L}-\mathrm{t}$ than did the $W$ rats $(p=.04)$ and in Experiments 1 and 2, the W rats drank more D-t than did the FH rats $(p=.01)$. The W stock drank more D-t than L-t in all three experiments $(p=.02)$, and FH rats drank more L-t than D-t ( $p s=.08$ and .04 , respectively) in Experiments 1 and 2. In Experiment 3, the FH rats drank equivalent amounts of D-t and L-t and as much D-t as did the $W$ rats. The W rats drank more D-t than L-t $(p=.02)$. In Experiment 2 , both stocks drank more $S$ than D-t or water $(p=$ .02 ). The $W$ rats drank more $S$ than $L-t$, but the $F H$ rats drank equivalent amounts of $L-t$ and $S$. Also, the $W$ stock drank more $S$ than did FH rats $(p=.016)$. Both FH and W rats drank more PTC solution than either D-t or L-t (FH, $p=.005 ; \mathrm{W}, p=.02$ ). However, the FH rats drank more PTC than did the $\mathrm{W}$ rats $(p=.02)$. In Experi-

Table 2

Food Consumption and Fluid Intake of Fawnhooded and Wistar DAB Rat Stocks in Each Experiment

\begin{tabular}{|c|c|c|c|c|c|c|c|c|c|c|c|c|}
\hline \multirow{3}{*}{$\begin{array}{c}\text { Rat } \\
\text { Stock }\end{array}$} & \multicolumn{6}{|c|}{ Total Food Consumption (grams) } & \multicolumn{6}{|c|}{ Total Fluid Intake (grams) } \\
\hline & \multicolumn{2}{|c|}{ Week 1} & \multicolumn{2}{|c|}{ Week 2} & \multicolumn{2}{|c|}{ Week 3} & \multicolumn{2}{|c|}{ Week 1} & \multicolumn{2}{|c|}{ Week 2} & \multicolumn{2}{|c|}{ Week 3} \\
\hline & Median & Range & Median & Range & Median & Range & Median & Range & Median & Range & Median & Range \\
\hline \multicolumn{13}{|c|}{ Experiment 1} \\
\hline $\begin{array}{l}\text { FH } \\
\text { W }\end{array}$ & $\begin{array}{l}61 \\
63\end{array}$ & $\begin{array}{l}54-72 \\
55-74\end{array}$ & $\begin{array}{l}52 \\
65\end{array}$ & $\begin{array}{l}49-59 \\
59-70\end{array}$ & $\begin{array}{l}49 \\
69\end{array}$ & $\begin{array}{l}42-52 \\
62-75\end{array}$ & $\begin{array}{l}141 \\
139\end{array}$ & $\begin{array}{l}111-158 \\
111-186\end{array}$ & $\begin{array}{r}91 \\
115\end{array}$ & $\begin{array}{r}56-118 \\
102-239\end{array}$ & $\begin{array}{r}86 \\
103\end{array}$ & $\begin{array}{l}43-93 \\
79-149\end{array}$ \\
\hline \multicolumn{13}{|c|}{ Experiment 2} \\
\hline $\begin{array}{l}\text { FH } \\
\text { W }\end{array}$ & $\begin{array}{l}64 \\
84\end{array}$ & $\begin{array}{l}52-84 \\
73-87\end{array}$ & $\begin{array}{l}56 \\
78\end{array}$ & $\begin{array}{l}32-75 \\
67-87\end{array}$ & $\begin{array}{l}54 \\
86\end{array}$ & $\begin{array}{l}41-85 \\
64-88\end{array}$ & $\begin{array}{l}100 \\
114\end{array}$ & $\begin{array}{r}78-131 \\
112-145\end{array}$ & $\begin{array}{r}94 \\
156\end{array}$ & $\begin{array}{r}62-109 \\
117-164\end{array}$ & $\begin{array}{l}144 \\
103\end{array}$ & $\begin{array}{r}117-167 \\
73-139\end{array}$ \\
\hline \multicolumn{13}{|c|}{ Experiment 3} \\
\hline $\begin{array}{l}\text { FH } \\
\text { W }\end{array}$ & $\begin{array}{l}60 \\
67\end{array}$ & $\begin{array}{l}40-66 \\
49-77\end{array}$ & $\begin{array}{l}61 \\
75\end{array}$ & $\begin{array}{l}45-69 \\
64-79\end{array}$ & $\begin{array}{l}60 \\
74\end{array}$ & $\begin{array}{l}46-69 \\
61-84\end{array}$ & $\begin{array}{l}92 \\
96\end{array}$ & $\begin{array}{l}65-103 \\
72-127\end{array}$ & $\begin{array}{r}103 \\
97\end{array}$ & $\begin{array}{l}72-121 \\
70-116\end{array}$ & $\begin{array}{l}77 \\
93\end{array}$ & $\begin{array}{l}66-111 \\
69-128\end{array}$ \\
\hline
\end{tabular}

Note-In Experiments 1 and 3, there were no stock differences in total chow or fluid intake $(p>.10)$ during Week 1 . In Experiment 2, the differences during Week 1 were statistically significant ( $p=.02$ for food and $p=.004$ for fluid). When the experimental fluids were presented (Weeks 2 and 3), the stock differences in total food eaten were significant $(p<.05)$ in all experiments. During those weeks, differences between the two stocks in fluid intake were statistically significant in Experiments 1 and $2(p=.05)$ but not in Experiment $3(p>.10$ for food and $p=.06$ for fluid). FH = Fawnhooded; $\mathbf{W}=$ Wistar. 
Table 3

Total Intake (in grams) of Water and Each Solution Presented to Fawnhooded and Wistar DAB Rat Stocks in Experiments 1-3

\begin{tabular}{|c|c|c|c|c|c|c|c|c|c|c|}
\hline \multirow{2}{*}{$\begin{array}{c}\text { Rat } \\
\text { Stock }\end{array}$} & \multicolumn{2}{|c|}{ D-t* } & \multicolumn{2}{|c|}{ L-t $\dagger$} & \multicolumn{2}{|c|}{ Water } & \multicolumn{2}{|c|}{$S^{*}$} & \multicolumn{2}{|c|}{ PTC } \\
\hline & Median & Range & Median & Range & Median & Range & Median & Range & Median & Range \\
\hline \multicolumn{11}{|c|}{ Experiment 1} \\
\hline $\begin{array}{l}\text { FH } \\
\text { W }\end{array}$ & $\begin{array}{l}10 \\
22\end{array}$ & $\begin{array}{l}5-14 \\
7-44\end{array}$ & $\begin{array}{l}16 \\
10\end{array}$ & $\begin{array}{r}10-32 \\
7-20\end{array}$ & $\begin{array}{l}55 \\
26\end{array}$ & $\begin{array}{l}25-73 \\
12-76\end{array}$ & & & & \\
\hline
\end{tabular}

Experiment 2

\begin{tabular}{lrrrrrrrrr} 
FH & 10 & $5-16$ & 28 & $11-45$ & 23 & $9-46$ & 33 & $16-57$ \\
W & 27 & $18-35$ & 13 & $6-25$ & 33 & $20-43$ & 79 & $19-103$ \\
& & & \multicolumn{8}{c}{ Experiment 3} \\
FH & 12 & $6-13$ & 11 & $8-25$ & 43 & $20-59$ & 45 & $25-59$ \\
W & 12 & $8-14$ & 8 & $4-13$ & 40 & $17-44$ & 29 & $12-52$ \\
\hline
\end{tabular}

Note-The water and solutions were presented daily for 2 weeks, from 0900 to $1100 \mathrm{~h}$, in two-bottle presentations of fluid combinations. D-t $=$ D-tryptophan, $\mathrm{L}-\mathrm{t}=\mathrm{L}$-tryptophan, $\mathrm{S}=$ saccharin, $\mathrm{PTC}=$ phenylthiocarbamide. FH $=$ Fawnhooded; $\mathrm{W}=$ Wistar. *Sweet tasting. †Bitter tasting.

ment $1, \mathrm{~W}$ rats drank water and D-t equivalently. In Experiment 2 , FH rats drank $L-t$ and water equivalently, whereas the $\mathrm{W}$ rats tended to drink more water than $\mathrm{D}-\mathrm{t}$ $(p=.06)$. In all other comparisons, both stocks drank more water than tryptophan solutions $(p=.02)$.

In all three experiments, the FH rats drank more L-t than did the $\mathrm{W}$ rats, and the $\mathrm{W}$ rats drank more $\mathrm{D}-\mathrm{t}$ than $L-t$. In two experiments, the $W$ rats drank more D-t than did the FH rats and the FH rats drank more L-t than D-t.

In the third experiment, when PTC was presented, a change emerged in the relative intakes of $D-t$ and $L-t$ by the two stocks: The FH rats drank as much D-t as did the W stock and drank as much D-t as L-t, although they drank more $L-t$ than the $W$ rats. It is possible that PTC affected the intake pattern of the two stocks simply because it was a new, or unusual, substance. However, in Experiment 2, in which $S$ was the new substance, the relationships between the two stocks in their differential intake of D-t and L-t remained as it had been in the first experiment, in which only the two tryptophans and water were presented. Both stocks drank large amounts of S; however, the $\mathrm{W}$ rats drank more $S$ than did the FH rats, and they drank more $S$ than D-t, whereas the $F H$ rats drank the same amounts of the sweet-tasting $S$ and the bitter-tasting L-t. Both stocks drank more PTC than either of the tryptophans, but, although both drank equal amounts of water, the FH rats drank more PTC than did the $\mathrm{W}$ rats.

It was possible that pairing the tryptophans with PTC affected the intake pattern differences, whereas pairing with $S$ or water did not. Accordingly, a further analysis was undertaken to examine the effects of PTC, S, and water when these were present in the combinations.

The intake amounts of D-t and L-t when they were paired with PTC, S, or water are presented in Table 4. The results of the statistical analysis of the data are presented in Table 5. All tests were one-tailed.

The total amounts of D-t and L-t intake in the third experiment seemed to indicate a lack of differences in D-t
Table 4

Intake (in Grams) of the Two Tryptophans When Paired with the Same Other Fluids

FH $\quad$ w

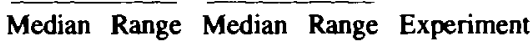

Intake of D-t when presented with:

$\begin{array}{lllrll}\text { L-t } & 4 & 0-8 & 9 & 3-21 & 1 \\ & 4 & 1-8 & 12 & 4-16 & 2 \\ \text { PTC } & 4 & 2-10 & 8 & 5-11 & 3 \\ \text { S } & 1 & 0-8 & 1 & 0-2 & 3 \\ \text { Water } & 3 & 2-8 & 7 & 4-10 & 2 \\ & 5 & 4-8 & 12 & 4-23 & 1 \\ & 2 & 0-8 & 9 & 0-17 & 2 \\ & 3 & 2-7 & 3 & 1-7 & 3\end{array}$

Intake of $\mathbf{L}-\mathrm{t}$ when presented with:

$\begin{array}{lrllll}\text { D-t } & 12 & 2-15 & 5 & 1-10 & 1 \\ & 5 & 3-12 & 6 & 1-9 & 2 \\ \text { PTC } & 4 & 1-12 & 1 & 0-7 & 3 \\ \text { S } & 6 & 4-9 & 6 & 3-8 & 3 \\ \text { Water } & 8 & 2-16 & 3 & 0-13 & 2 \\ & 4 & 3-12 & 5 & 3-10 & 1 \\ & 10 & 1-17 & 3 & 0-9 & 2 \\ & 2 & 1-4 & 2 & 0-2 & 3\end{array}$

Note-WITHIN STOCKS: For Experiment 1, sign tests for different intakes of D-t and $L-t$ in combination with water or each other gave the following results: FH-D-t, $p=.109$; L-t, $p=.06 ; \mathrm{W}$, differences not statistically significant. For Experiments 2 and 3, Friedman ANOVAs were used for D-t and L-t in combination with each other, or with S, or PTC, and water. In Experiment 2, the differences were not statistically significant for either stock. In Experiment 3, FH, D-t intake differences not significant; L-t, $p \leq .01$; W, D-t and L-t, $p \leq .01$. In Experiment 2 , sign tests for paired comparisons within stocks indicated: FH, L-t intake when with water or D-t, $p=.109$; W, L-t intake when with water or D-t, $p=.05$. In Experiment 3, sign tests indicated: $F H$, D-t intake when with L-t or PTC, $p=.06$, when with water or PTC, $p=.109$; L-t paired with PTC or water, $p=.03 ; \mathrm{W}$, all appropriate comparisons, $p=.03$, except for $L-t$ when paired with $D-t$ or water, in which case the difference was not significant. BETWEEN STOCKS: Experiment 1, D-t presented with L-t or with water, and L-t presented with D-t, $p \leq .05$. Experiment 2 , D-t presented with L-t, S, or water, and $L-t$ presented with $S$ or water, $p \leq .05$. Experiment 3, D-t presented with L-t, $p=.06$; L-t presented with D-t, $p=.05$. D-t $=$ D-tryptophan, L-t $=$ L-tryptophan, PTC = phenylthiocarbamide, $\mathbf{S}=$ saccharin. $\mathbf{F H}=$ fawnhooded; $\mathbf{W}=$ Wistar. 
Table 5

Statistical Analysis of D-t and L-t Intake Differentials (Data in Table 4)

\begin{tabular}{|c|c|c|c|c|c|}
\hline & \multirow{2}{*}{$\begin{array}{l}\text { Expected } \\
\text { Direction }\end{array}$} & \multirow{2}{*}{$\begin{array}{l}\text { When } \\
\text { Presented With: }\end{array}$} & \multicolumn{3}{|c|}{ Experiments } \\
\hline & & & 1 & 2 & 3 \\
\hline \multicolumn{6}{|c|}{ Between-Stock Comparisons* } \\
\hline $\begin{array}{r}\text { Fluid: } \\
\text { D-t }\end{array}$ & $\mathbf{W}>\mathbf{F H}$ & $\begin{array}{l}\text { L-t } \\
\text { PTC } \\
\text { S } \\
\text { Water }\end{array}$ & $\begin{array}{c}.05 \\
- \\
- \\
.05\end{array}$ & $\begin{array}{c}.05 \\
- \\
.05 \\
.05\end{array}$ & $\begin{array}{c}.08 \\
\text { n.s. } \\
- \\
\text { n.s. }\end{array}$ \\
\hline L-t & FH $>$ W & $\begin{array}{l}\text { D-t } \\
\text { PTC } \\
\text { S } \\
\text { Water }\end{array}$ & $\begin{array}{c}.05 \\
- \\
- \\
\text { n.s. }\end{array}$ & $\begin{array}{c}\text { n.s. } \\
- \\
.05 \\
.05\end{array}$ & $\begin{array}{c}.05 \\
\text { n.s } \\
- \\
\text { n.s. }\end{array}$ \\
\hline \multicolumn{6}{|c|}{ Within-Stock Comparisons $\dagger$} \\
\hline $\begin{array}{c}\text { Stock: } \\
\text { FH }\end{array}$ & L-t $>$ D-t & $\begin{array}{l}\text { Each other } \\
\text { PTC } \\
\text { S } \\
\text { Water }\end{array}$ & $\begin{array}{c}.035 \\
- \\
- \\
\text { n.s. }\end{array}$ & $\begin{array}{l}\text { n.s. } \\
-008 \\
.06\end{array}$ & $\begin{array}{c}\text { n.s. } \\
.035 \\
- \\
\text { n.s. }\end{array}$ \\
\hline $\mathbf{w}$ & D-t $>$ L-t & $\begin{array}{l}\text { Each other } \\
\text { PTC } \\
\text { S } \\
\text { Water }\end{array}$ & $\begin{array}{c}.035 \\
- \\
- \\
.016\end{array}$ & $\begin{array}{c}\text { n.s. } \\
- \\
\text { n.s. } \\
.109\end{array}$ & $\begin{array}{c}.035 \\
.004 \\
- \\
\text { n.s. }\end{array}$ \\
\hline
\end{tabular}

Note-D-t $=$ D-tryptophan, $\mathrm{L}-\mathrm{t}=\mathrm{L}$-tryptophan, PTC $=$ phenylthiocarbamide, $S=$ saccharin. $\mathbf{F H}=$ Fawnhooded; $W=$ Wistar. ${ }^{*}$ Median test. †Sign test, one-tailed. $\ddagger W$ drank more L-t than D-t.

intake by the two stocks, and of D-t and L-t intake by the FH rats. However, the data in Table 4 show that when the two stocks were offered D-t and L-t tastes at the same time, the stock difference in enantiomer intake persisted. Comparison of D-t and L-t intake within each stock when the enantiomers are presented in different combinations, however, reveals that $S$ affected both FH and W rat intake when they were presented with each other. But, FH continued to drink more L-t than D-t when presented with $S$, whereas W did not. Both showed the expected stock differential when D-t and $L-t$ were presented with water.

PTC countered the enantiomer differential intake in the FH rats when they were presented with each other, but this was not true for the $\mathrm{W}$ rat $(p=.035)$. The saliency of the effect of PTC on the W rat is also seen in the fact that the W rats drank more L-t than D-t when they were presented with PTC, but not when they were presented with water. On the other hand, the FH rats continued to drink more L-t than D-t when they were presented with PTC.

It would appear that there are differences between the two stocks in their responses to the sweet and bitter tastes of different substances, as well as to the two tryptophan enantiomers. The effect of cross-adaptation (McBumey \& Gent, 1979) and other factors on the sensitivity of the two stocks to the tastes and to the different forms of tryptophan requires further study. That the $\mathrm{FH}$ is drinking L-t for reasons other than its bitter taste seems to be indicated.

\section{REFERENCES}

MCBuRNEY, D. H., \& GeNT, J. F. (1979). On the nature of taste qualities. Psychological Bulletin, 86, 151-167.

PACHeco, T. (1986). Differential intake of D- and L-tryptophan solutions by three (DAB) stocks of rats: Fawnhooded, Long-Evans, and Wistar (Rattus norvegicus). Unpublished master's thesis, City University of New York.

Pritchard, T. C., \& Scott, R. (1982). Amino acids and taste stimuli: I. Neural and behavioral attributes. Brain Research, 253, 81-92.

RAYmond, S. L., \& DodDS, W. J. (1975). Characteristics of the fawnhooded rat as a model for hemostatic studies. Thrombosis et Diathesis Haemorrhagica, 33, 361-369.

Rosoff, B., Yamashita, H., \& TOBach, E. (1985). Pineal function in fawnhooded (DAB) rats. In M. J. Baum, J. T. Potts, Jr., \& R. J. Wurtman (Eds.), Medical and biological effects of light. Annals of the New York Academy of Sciences, 453, 401-405.

SIEGEL, S. (1956). Non-parametric statistics for the behavioral sciences. New York: McGraw-Hill.

Silver, B., Hernandez, T., Tobach, E. (1988). Fawn coat color, audiogenic seizure susceptibility and clotting times in a "wild" population of Rattus norvegicus. Manuscript in preparation.

Tobach, E., Bellin, J. S., \& DAs, D. K. (1974). Differences in bitter taste perception in three strains of rats. Behavior Genetics, 4, 405-410.

Toвach, E., DeSANTIS, J. L., Z ZuCKER, M. B. (1984). Platelet storage pool disease in hybrid rats. Journal of Heredity, 75, 15-18.

TsCHOPP, T. B., \& ZUCKER, M. B. (1972). Heredity defect in platelet function in rats. Blood, 40, 217-226.

(Manuscript received October 18, 1987; revision accepted for publication March 25, 1988.) 